\title{
PREFERENSI PEMILIHAN PERUMAHAN DI PINGGIRAN KOTA SURAKARTA BERDASARKAN MOTIVASI PEMBELIAN RUMAH
}

\author{
Sigit Nugroho, Achmad Djunaedi, Doddy Aditya Iskandar \\ Jurusan Teknik Arsitektur dan Perencanaan, Fakultas Teknik, Unversitas Gadjah Mada \\ Jl. Grafika No. 2 Kampus UGM, Yogyakarta 55281 \\ sigit.nugh@gmail.com
}

\begin{abstract}
ABSTRAK
Pertumbuhan penduduk yang cepat di Kota Surakarta membutuhkan kebutuhan lahan untuk perumahan. Akibat keterbatasan lahan yang ada, pemenuhan kebutuhan perumahan menyebar hingga wilayah pinggiran kota di sekitar Kota Surakarta. Dalam memilih rumah, baik itu sebagai konsumsi ataupun investasi, kemungkinan tiap individu atau keluarga akan mempunyai preferensi yang berbeda-beda tergantung pada karakteristiknya. Tujuan penelitian ini adalah untuk mengetahui preferensi pemilihan perumahan berdasarkan motivasi pembelian rumah dan untuk mengetahui hubungan karakteristik rumah tangga dengan motivasi dalam membeli rumah. Metode yang digunakan adalah metode deskriptif kuantitatif dengan analisis kecenderungan persentase dan rata-rata untuk mengetahui preferensi pemilihan perumahan dan analisis tabulasi silang dan uji Chi-Square untuk mengetahui hubungan antara karakteristik rumah tangga dengan motivasi pembelian rumah. Hasil dari analis preferensi pemilihan perumahan adalah, pada rumah tangga yang membeli rumah untuk motivasi konsumsi, preferensi utama dalam pemilihan perumahan adalah: 1) kondisi fisik lingkungan $(2,84)$; 2) pembiayaan rumah $(2,76)$; dan 3) lokasi dan aksesibilitas (2,76). Sedangkan pada rumah tangga yang mempunyai motivasi untuk investasi, preferensi utama dalam pemilihan perumahan adalah: 1) kondisi fisik rumah $(2,83)$; 2) lokasi dan aksesibilitas $(2,80)$; dan 3) kondisi fisik lingkungan $(2,78)$. Karakteristik rumah tangga yang berpengaruh terhadap motivasi pembelian rumah adalah tingkat pendidikan (sig. 0,000); tingkat penghasilan keluarga (sig. 0,001) dan tipe perumahan (sig. 0,006). Dengan diketahuinya preferensi pemilihan perumahan berdasarkan motivasi pembelian diharapkan dapat dijadikan bahan masukan dalam pembuatan kebijakan bagi pemerintah dalam pembangunan perumahan terutama dalam pemenuhan kebutuhan perumahan agar tepat sasaran, terutama bagi masyarakat yang berpenghasilan rendah yang sebagian besar masih mempunyai kesulitan akses untuk memiliki perumahan.
\end{abstract}

Kata Kunci : pemilihan perumahan, motivasi pembelian rumah, daerah pinggiran kota

\section{ABSTRACT}

Rapid population growth in Surakarta requires the need for land for housing. Due to limited land available, the fulfillment of housing needs spread to the suburbs around the city of Surakarta. In choosing a home, whether it be consumption or investment, the convenience of individuals or households will have different preferences depending on the characteristics. The purpose of this study is to determine the preferences of housing selection based on the motivation of home purchase and to know the relationship of household characteristics with motivation of home purchase. The method used is quantitative descriptive method with percentage tendency and mean analysis to know housing selection preferences and cross tabulation analysis and Chi-Square test to know the relation between household characteristics and motivation of home purchase. The result of the analysis of housing preferences is, in households that buy houses for consumption, the main preference in housing selection is: 1) the physical condition of the environment (2.84); 2) home financing (2.76); and 3) location and accessibility (2.76). While in households that have motivations for investment, the main preference in housing selection is: 1) the physical condition of the house (2.83); 2) location and accessibility (2.80); and 3) the physical condition of the environment (2.78). Characteristics of households that influence the motivation of home purchase is the level of education (sig. 0.000); households income level (sig 0.001) and housing type (sig 0.006. With the knowledge of housing selection preference based on purchasing motivation, it is hoped that it can be used as input in making policy for the government in housing development especially in fulfilling the needs of housing for the right target, especially for low income people who mostly still have difficulty access to own housing.

Keywords: selection of housing, motivation of home purchase, sub-urban area

\section{PENDAHULUAN}

Pertumbuhan jumlah penduduk perkotaan yang disertai oleh meningkatnya kebutuhan dalam aspek-aspek politik, ekonomi, sosial, budaya, dan teknologi akan mendorong peningkatan kegiatan penduduk perkotaan. Dengan bertambahnya jumlah penduduk dalam suatu wilayah perkotaan maka kebutuhan akan ruang untuk tempat tinggal yang semakin meningkat, demikian pula dengan adanya bertambahnya volume dan frekuensi 
kegiatan yang ada maka tuntutan untuk pertambahan ruang yang mengakomodasi kegiatan-kegiatan yang baru juga akan meningkat. Oleh karena ruang terbuka yang ada di dalam bagian kota semakin menyusut, maka tidak semua pertambahan tuntutan akan ruang baik untuk permukiman maupun kegiatan tersebut dapat terakomodasi, sehingga penambahan permukiman maupun kegiatan dilaksanakan di luar lahan kekotaan terbangun, atau di lahan-lahan terbuka yang masih berupa lahan-lahan pertanian (Yunus, 2012).

Keberadaan Kota Surakarta yang merupakan salah satu kota besar di Provinsi Jawa Tengah yang menjadi pusat kegiatan perekonomian, pendidikan, perdagangan, dan sektor informal akan menarik banyak para pendatang dari daerah sekitar maupun dari luar daerah yang datang ke Surakarta dengan tujuan untuk bekerja, sekolah, berdagang, dan sebagainya. Kondisi bertambahnya jumlah penduduk Kota Surakarta dan banyaknya pendatang dari luar daerah akan mengakibatkan kebutuhan akan tempat tinggal di wilayah Kota Surakarta juga akan meningkat. Akibat keterbatasan lahan yang ada, pemenuhan kebutuhan masyarakat akan perumahan di Kota Surakarta tidak saja terpusat di wilayah Kota Surakarta, tetapi juga menyebar hingga wilayah pinggiran kota di sekitar Kota Surakarta. Kondisi tersebut dimanfaatkan para pengembang (developer) untuk membangun perumahan dalam memenuhi kebutuhan perumahan. Lokasi perumahan tersebut banyak dibangun di daerah pinggiran Kota Surakarta, menyebar di wilayah yang berbatasan langsung dengan Kota Surakarta diantaranya di wilayah Kabupaten Karanganyar dan Kabupaten Sukoharjo.

Rumah (perumahan) merupakan salah satu kebutuhan dasar bagi setiap manusia, selain sandang dan pangan. Kebutuhan hidup manusia atas tempat tinggal yang nyaman, aman, dan tenang merupakan tujuan awal atas kebutuhan akan rumah. Saat ini, kepemilikan rumah atau tanah tidak hanya digunakan sebagai tempat tinggal saja, khususnya bagi kalangan masyarakat menengah keatas, kepemilikan rumah atau tanah dapat dijadikan sebagai barang investasi dalam jangka panjang dan dijadikan sebagai tolak ukur kesejahteraan manusia (Green, 1996).

Perumahan merupakan aset properti yang cukup unik dan multi fungsi. Unik karena aset ini tidak dapat dipindahkan lokasinya dan dapat bersifat prestise bagi pemiliknya. Multi fungsi karena selain dapat digunakan sebagai tempat tinggal, rumah juga dapat dijadikan sebagai alat investasi yang baik. Beberapa keunggulan dari investasi perumahan secara finansial antara lain: 1) Nilai tanah cenderung meningkat sehingga dapat dijadikan capital gain, 2) Dapat dijadikan sebagai pendapatan dari operasinya dalam bentuk sewa, 3) Sebagai agunan/jaminan yang baik dalam pengambilan kedit, 4) merupakan investasi jangka panjang yang aman (Ajusa, 2007).

Banyak faktor yang mempengaruhi keputusan suatu rumah tangga/keluarga untuk membeli suatu rumah, mengingat keputusan untuk membeli sebuah rumah adalah sebuah keputusan besar bagi sebagian besar keluarga. Faktor-faktor tersebut antara lain yang berkaitan dengan pembiayaan rumah, kondisi fisik rumah, lokasi, aksesibilitas, kondisi lingkungan dan ketersediaan fasilitas dan utilitas di dalam perumahan

Dalam memilih rumah, baik itu sebagai konsumsi ataupun investasi, kemungkinan tiap individu atau keluarga akan mempunyai preferensi yang berbeda-beda tergantung pada karakteristiknya. Jika pembeliannya berdasarkan motif konsumsi untuk kebutuhan dasar, mungkin akan menolak suatu rumah apabila rumah tersebut bukan merupakan rumah ideal yang ingin ditinggalinya, tetapi jika pertimbangan saat membeli rumah adalah untuk berinvestasi, maka aspek-aspek ekonomi dari rumah yang akan lebih dilihat (Utama, 2011).

Fenomena yang terlihat di wilayah pinggiran Kota Surakarta pada saat ini adalah banyak perumahan yang telah terbangun dan siap untuk dihuni tetapi belum digunakan atau tidak ditempati. Hal ini disebabkan oleh banyaknya pengembang perumahan yang terus melakukan pembangunan perumahan tanpa memperhatikan kebutuhan perumahan yang diinginkan oleh masyarakat. Kondisi tersebut dikhawatirkan akan menimbulkan terjadinya penguasaan perumahan dan lahan yang ada sebagai komoditi perdagangan dan barang investasi oleh masyarakat kalangan menengah atas, sedangkan bagi masyarakat berpenghasilan rendah akan semakin kesulitan untuk untuk memiliki akses untuk memiliki sebuah rumah.

Penelitian ini bertujuan untuk mengetahui preferensi pemilihan rumah berdasarkan motivasi dalam membeli rumah, yaitu apakah untuk konsumsi atau investasi. Selain itu juga untuk mengetahui hubungan karakteristik individu/rumah tangga dengan motivasi dalam membeli rumah. Dengan penelitian ini, diharapkan dapat diketahui preferensi pemilihan perumahan yang sesuai dengan kebutuhan masyarakat, sehingga dapat dijadikan bahan 
masukan dalam pembuatan kebijakan bagi pemerintah dalam pembangunan perumahan terutama dalam pemenuhan kebutuhan perumahan bagi masyarakat yang berpenghasilan rendah yang sebagian besar masih mempunyai kesulitan akses untuk memiliki perumahan. Selain itu penelitian juga diharapkan dapat dijadikan masukan bagi pengembang perumahan dalam melakukan pembangunan perumahan.

\section{METODE PENELITIAN}

Pendekatan yang digunakan dalam penelitian ini adalah pendekatan deduktif dengan metode analisis kuantitatif. Lokasi penelitian meliputi keseluruhan wilayah perumahan di daerah pinggiran Kota Surakarta. Daerah pinggiran Kota Surakarta yang dimaksud dalam penelitian ini adalah desa-desa di Kabupaten Karanganyar dan Sukoharjo yang berbatasan langsung dengan Kota Surakarta. Lokasi penelitian ini mencakup 33 desa dan 7 kecamatan.

Tabel 1. Wilayah Administratif Lokasi Penelitian

\begin{tabular}{|c|c|c|}
\hline Kabupaten & Kecamatan & Desa \\
\hline \multirow{11}{*}{ Karanganyar } & \multirow{7}{*}{ Colomadu } & Baturan \\
\hline & & Blulukan \\
\hline & & Gajahan \\
\hline & & Klodran \\
\hline & & Paulan \\
\hline & & Tohudan \\
\hline & & Gedongan \\
\hline & \multirow{2}{*}{ Gondangrejo } & Plesungan \\
\hline & & Wonorejo \\
\hline & \multirow{2}{*}{ Jaten } & Ngringo \\
\hline & & Sroyo \\
\hline \multirow{22}{*}{ Sukoharjo } & \multirow{4}{*}{ Baki } & Siwal \\
\hline & & Gentan \\
\hline & & Waru \\
\hline & & Kadilanggu \\
\hline & \multirow{8}{*}{ Grogol } & Kwarasan \\
\hline & & Madegondo \\
\hline & & Kadokan \\
\hline & & Banaran \\
\hline & & Cemani \\
\hline & & Grogol \\
\hline & & Manang \\
\hline & & Gedangan \\
\hline & \multirow{5}{*}{ Kartasura } & Gumpang \\
\hline & & Gonilan \\
\hline & & Singopuran \\
\hline & & Pabelan \\
\hline & & Makamhaji \\
\hline & \multirow{5}{*}{ Mojolaban } & Palur \\
\hline & & Gadingan \\
\hline & & Laban \\
\hline & & Wirun \\
\hline & & Plumbon \\
\hline
\end{tabular}

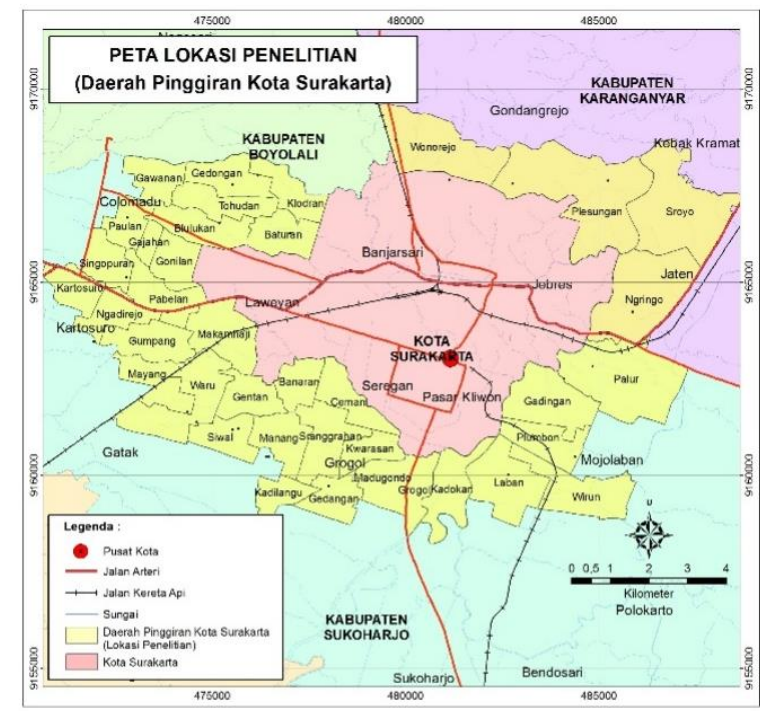

Gambar 1. Peta Lokasi Penelitian (Daerah Pinggiran Kota Surakarta)

Populasi dalam penelitian ini adalah seluruh perumahan yang ada wilayah pinggiran Kota Surakarta yang dibangun setelah tahun 2014 oleh pihak swasta/real estateldeveloper. Dari data yang diperoleh dari dinas terkait, jumlah perumahan yang ada di wilayah penelitian adalah sebanyak 106 perumahan. Dalam penelitian ini dipilih sebanyak 24 perumahan yang dianggap mewakili seluruh populasi yang ada.

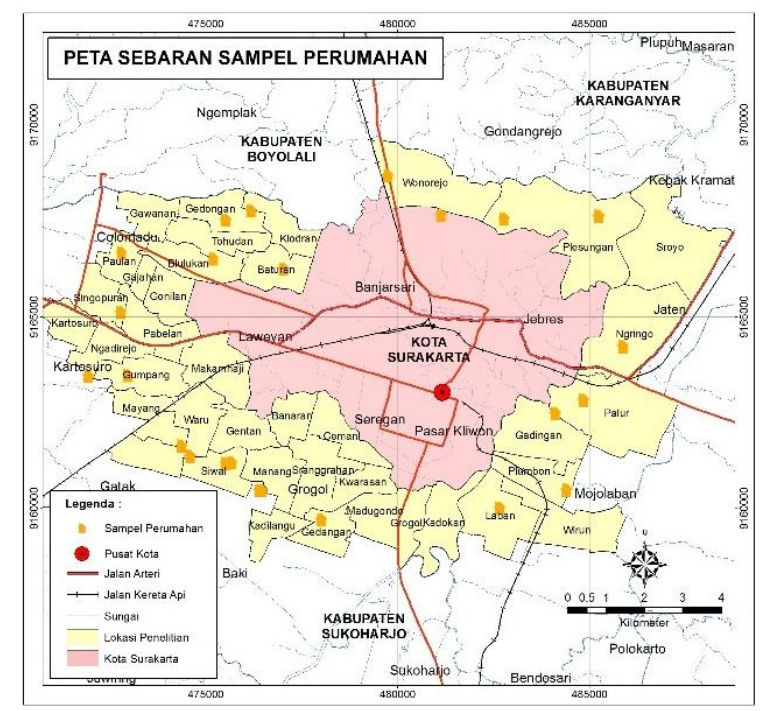

Gambar 2. Peta Sebaran Sampel Perumahan

Dari 24 perumahan yang dipilih kemudian diambil sampel rumah tangga/keluarga sebagai unit amatan. Dalam penelitian ini jumlah sampel rumah tangga ditentukan dengan menggunakan rumus Slovin. Perhitungan dengan rumus Slovin adalah sebagai berikut: 


$$
n=\frac{N}{1+N e^{2}}
$$

Keterangan :

$\mathrm{n}=$ Jumlah/ukuran sampel

$\mathrm{N}=$ Jumlah populasi

$e=$ Batas toleransi kesalahan (error tolerance)

Dalam penelitian ini diketahui N (jumlah populasi) sebesar 1054 unit rumah. Dengan menggunakan derajat kepercayaan (confidence level) sebesar 90\% (batas toleransi kesalahan 0.1), maka jumlah minimal sampel yang diambil oleh peneliti adalah sebesar :

$$
\begin{aligned}
& n=\frac{N}{1+N e^{2}} \\
& n=\frac{1054}{1+\left(1054 \cdot 0,1^{2}\right)} \\
& n=91,3344 \sim 91
\end{aligned}
$$

Dengan menggunakan rumus slovin pada perhitungan diatas, maka didapatkan jumlah sampel sebanyak 91 unit rumah.

Tabel 2. Jumlah Sampel pada Tiap Perumahan

\begin{tabular}{|r|l|l|r|r|}
\hline No & Nama Perumahan & Desa & $\begin{array}{c}\text { Jumlah } \\
\text { Rumah } \\
\text { (Unit) }\end{array}$ & $\begin{array}{r}\text { Jumlah } \\
\text { Sampel }\end{array}$ \\
\hline 1 & Green Garden Res. & Baturan & 40 & 3 \\
\hline 2 & Flamboyan Indah 3 & Blulukan & 36 & 3 \\
\hline 3 & Griya Sakinah & Gedongan & 66 & 6 \\
\hline 4 & Griya Gedongan Indah & Gedongan & 66 & 6 \\
\hline 5 & Aliza Residence & Paulan & 28 & 2 \\
\hline 6 & Zada Regency 3 & Plesungan & 100 & 9 \\
\hline 7 & Duta Permata Sakti & Plesungan & 36 & 3 \\
\hline 8 & Permata Wonorejo & Wonorejo & 100 & 9 \\
\hline 9 & Peni Regency 8 & Wonorejo & 20 & 2 \\
\hline 10 & Griya Winong Baru & Ngringo & 56 & 5 \\
\hline 11 & Citra Mulia & Siwal & 50 & 4 \\
\hline 12 & Graha Utama & Siwal & 28 & 2 \\
\hline 13 & Queen Garden 7 & Waru & 32 & 3 \\
\hline 14 & Dukuh Asri Res. & Waru & 20 & 2 \\
\hline 15 & Griya Bintang Res. & Kadilanggu & 32 & 3 \\
\hline 16 & Bumi Manang Asri & Manang & 26 & 2 \\
\hline 17 & Peni Regency 2 & Gedangan & 40 & 3 \\
\hline 18 & Soditan Permai & Gumpang & 56 & 5 \\
\hline 19 & Puri Permata Keira & Gumpang & 32 & 3 \\
\hline 20 & Taman Kuantan & Singopuran & 24 & 2 \\
\hline 21 & Bale Wening & Laban & 22 & 2 \\
\hline 22 & Grand Residence & Gadingan & 40 & 3 \\
\hline 23 & Griya Adi Palur & Palur & 60 & 5 \\
\hline 24 & Gardena Palm Asri & Plumbon & 46 & 4 \\
\hline & & & $\mathbf{1 0 5 4}$ & $\mathbf{9 1}$ \\
\hline
\end{tabular}

Dalam penelitian ini, variabel-variabel yang

\begin{tabular}{|c|c|}
\hline Variabel & Indikator \\
\hline $\begin{array}{c}\text { Pembiayaan } \\
\text { Rumah }\end{array}$ & $\begin{array}{l}\text { a. Harga rumah } \\
\text { b. Besarnya uang muka } \\
\text { c. Besarnya Angsuran } \\
\text { d. Tingkat suku bunga } \\
\text { e. Status hukum tanah }\end{array}$ \\
\hline $\begin{array}{c}\text { Kondisi } \\
\text { Fisik Rumah }\end{array}$ & $\begin{array}{l}\text { a. Tipe rumah } \\
\text { b. Luas tanah kapling } \\
\text { c. Kualitas bangunan } \\
\text { d. Jumlah kamar } \\
\text { e. Bentuk/model bangunan }\end{array}$ \\
\hline $\begin{array}{c}\text { Lokasi dan } \\
\text { Aksesibilitas }\end{array}$ & $\begin{array}{ll}\text { a. } & \text { Jarak ke pusat kota } \\
\text { b. } & \text { Jarak ke tempat kerja } \\
\text { c. } & \text { Lebar jalan lingkungan } \\
\text { d. } & \text { Kondisi jalan lingkungan } \\
\text { e. } & \text { Jarak dengan jalan utama } \\
\text { f. } & \text { Jarak dengan jalur angkutan umum } \\
\text { g. } & \text { Jarak dengan pusat perbelanjaan } \\
\text { h. Jarak dengan sarana pendidikan } \\
\text { i. Jarak dengan sarana kesehatan } \\
\text { j. Jarak dengan pasar/pertokoan }\end{array}$ \\
\hline $\begin{array}{c}\text { Kondisi } \\
\text { Fisik } \\
\text { Lingkungan }\end{array}$ & $\begin{array}{ll}\text { a. } & \text { Ketersediaan ruang terbuka } \\
\text { b. } & \text { Keindahan dan kebersihan } \\
\text { c. } & \text { View/pemandangan lingkungan } \\
\text { d. Ketenangan/tingkat kebisingan } \\
\text { e. Kerawanan bencana } \\
\text { f. } \\
\text { g. } \\
\text { holusi udara } \\
\text { h. Kondisi iklim (suhu udara) }\end{array}$ \\
\hline $\begin{array}{c}\text { Kondisi } \\
\text { Sosial } \\
\text { Lingkungan }\end{array}$ & $\begin{array}{ll}\text { a. Keamanan } \\
\text { b. Nilai prestise } \\
\text { c. Kedekatan dengan kerabat/saudara } \\
\text { d. Persamaan status sosial } \\
\text { e. Persamaan status ekonomi }\end{array}$ \\
\hline $\begin{array}{l}\text { Ketersediaan } \\
\text { Fasilitas dan } \\
\text { Utilitas }\end{array}$ & $\begin{array}{l}\text { a. Ketersediaan tempat ibadah } \\
\text { b. Ketersediaan tempat bermain anak } \\
\text { c. Ketersediaan sarana olahraga } \\
\text { d. Ketersediaan jaringan listrik } \\
\text { e. Ketersediaan sumber air bersih } \\
\text { f. Ketersediaan jaringan telepon }\end{array}$ \\
\hline
\end{tabular}
digunakan untuk mengetahui preferensi pemilihan perumahan adalah sebagai berikut:

Tabel 3. Variabel Penelitian

Pengumpulan data dilakukan dengan cara survey untuk mendapatkan data, baik data primer maupun data sekunder. Pengumpulan data primer melalui observasi/pengamatan langsung yang dilakukan dengan mencatat keadaan fisik dan lingkungan perumahan. Selain itu dilakukan juga wawancara terhadap penghuni perumahan berkaitan dengan data umum responden dan preferensi pemilihan perumahan dengan menggunakan kuesioner.

Metode analisis yang digunakan yaitu:

1. Analisis deskriptif kuantitatif dengan analisis kecenderungan persentase dan analisis ratarata, untuk menjelaskan variabel yang menjadi preferensi pemilihan perumahan berdasarkan motivasi pembelian rumah. Data preferensi konsumen terhadap pemilihan perumahan 
diolah dari hasil kuesioner preferensi pemilihan perumahan berdasarkan indikatorindikator pemilihan lokasi perumahan yang ditanyakan dalam kuesioner. Hasil jawaban konsumen berdasarkan indikator-indikator tersebut kemudian dikuantifikasikan dalam skala ordinal atau skala likert. Skala likert yang digunakan dalam penelitian ini menggunakan lima tingkat preferensi jawaban berdasarkan tingkat kepentingan indikator sebagai pertimbangan dalam pemilihan perumahan. Setelah masing-masing indikator dihitung kemudian dilakukan analisis data perhitungan skor yang pada masing-masing variabel dengan menggunakan analisis kecenderungan persentase dan rata-rata.

Tabel 4. Tingkatan Skala Likert

\begin{tabular}{|c|c|c|}
\hline Angka & Kode & Keterangan \\
\hline 5 & SP & Sangat Penting \\
\hline 4 & P & Penting \\
\hline 3 & N & Netral \\
\hline 2 & TP & Tidak Penting \\
\hline 1 & STP & Sangat Tidak Penting \\
\hline
\end{tabular}

Tabel 5. Pengukuran Faktor-Faktor yang Mempengaruhi Pemilihan Perumahan

\begin{tabular}{|c|c|c|c|}
\hline Faktor & $\begin{array}{c}\text { Jumlah } \\
\text { Indikator }\end{array}$ & $\begin{array}{c}\text { Penentuan Skor } \\
\text { (Skala Likert) }\end{array}$ & Penentuan Kategori \\
\hline $\begin{array}{c}\text { Pembiayaan } \\
\text { Rumah }\end{array}$ & 5 & $\begin{array}{l}\text { Skor 1 = nilai } \\
\text { terendah } \text { (sangat } \\
\text { tidak penting) } \\
\text { dan Skor } 5=\text { nilai } \\
\text { tertinggi (sangat } \\
\text { penting) }\end{array}$ & $\begin{array}{l}\text { Nilai Maks: } 25 \\
\text { Nilai Min: } 5 \\
\text { Jumlah kategori: } 3 \\
\text { Interval kelas: } 7 \\
\text { Kategori: } \\
\text {-TM (total skor <12) } \\
\text {-CM (total skor } 12-19 \text { ) } \\
\text {-SM (total skor }>19 \text { ) }\end{array}$ \\
\hline $\begin{array}{c}\text { Kondisi } \\
\text { Fisik Rumah }\end{array}$ & 5 & $\begin{array}{l}\text { Skor } 1=\text { nilai } \\
\text { terendah } \text { (sangat } \\
\text { tidak penting) } \\
\text { dan Skor } 5=\text { nilai } \\
\text { tertinggi (sangat } \\
\text { penting) }\end{array}$ & $\begin{array}{l}\text { Nilai Maks: } 25 \\
\text { Nilai Min: } 5 \\
\text { Jumlah kategori: } 3 \\
\text { Interval kelas: } 7 \\
\text { Kategori: } \\
\text {-TM (total skor <12) } \\
\text {-CM (total skor 12-19) } \\
\text {-SM (total skor }>19 \text { ) }\end{array}$ \\
\hline $\begin{array}{c}\text { Lokasi dan } \\
\text { Aksesibilitas }\end{array}$ & 10 & $\begin{array}{l}\text { Skor } 1=\text { nilai } \\
\text { terendah } \text { (sangat } \\
\text { tidak penting) } \\
\text { dan Skor } 5=\text { nilai } \\
\text { tertinggi (sangat } \\
\text { penting) }\end{array}$ & $\begin{array}{l}\text { Nilai Maks:50 } \\
\text { Nilai Min: } 10 \\
\text { Jumlah kategori: } 3 \\
\text { Interval kelas: } 13 \\
\text { Kategori: } \\
\text {-TM (total skor <23) } \\
\text {-CM (total skor } 24-36 \text { ) } \\
\text {-SM (total skor }>36 \text { ) }\end{array}$ \\
\hline $\begin{array}{c}\text { Kondisi } \\
\text { Fisik } \\
\text { Lingkungan }\end{array}$ & 8 & $\begin{array}{l}\text { Skor } 1=\text { nilai } \\
\text { terendah } \text { (sangat } \\
\text { tidak penting) } \\
\text { dan Skor } 5=\text { nilai } \\
\text { tertinggi (sangat } \\
\text { penting) }\end{array}$ & $\begin{array}{l}\text { Nilai Maks: } 40 \\
\text { Nilai Min: } 8 \\
\text { Jumlah kategori: } 3 \\
\text { Interval kelas: } 11 \\
\text { Kategori: } \\
\text {-TM (total skor }<19 \text { ) } \\
\text {-CM (total skor } 20-30 \text { ) } \\
\text {-SM (total skor }>30 \text { ) }\end{array}$ \\
\hline $\begin{array}{c}\text { Kondisi } \\
\text { Sosial } \\
\text { Lingkungan }\end{array}$ & 5 & $\begin{array}{l}\text { Skor } 1=\text { nilai } \\
\text { terendah } \text { (sangat } \\
\text { tidak penting) } \\
\text { dan Skor } 5=\text { nilai } \\
\text { tertinggi (sangat } \\
\text { penting) }\end{array}$ & $\begin{array}{l}\text { Nilai Maks: } 25 \\
\text { Nilai Min: } 5 \\
\text { Jumlah kategori: } 3 \\
\text { Interval kelas: } 7 \\
\text { Kategori: } \\
\text {-TM (total skor <12) } \\
\text {-CM (total skor } 12-19 \text { ) } \\
\text {-SM (total skor }>19 \text { ) }\end{array}$ \\
\hline
\end{tabular}

\begin{tabular}{|c|c|l|l|}
\hline Faktor & $\begin{array}{c}\text { Jumlah } \\
\text { Indikator }\end{array}$ & $\begin{array}{l}\text { Penentuan Skor } \\
\text { (Skala Likert) }\end{array}$ & \multicolumn{1}{|c|}{ Penentuan Kategori } \\
\hline & & $\begin{array}{l}\text { Skor 1 = nilai } \\
\text { terendah (sangat } \\
\text { tidak penting) }\end{array}$ & $\begin{array}{l}\text { Nilai Maks: } 30 \\
\text { Nilai Min: 6 } \\
\text { Jumlah kategori: 3 }\end{array}$ \\
$\begin{array}{c}\text { Ketersediaan } \\
\text { tertinggi } \text { (sangat } \\
\text { penting) }\end{array}$ & $\begin{array}{l}\text { Interval kelas: } 8 \\
\text { Kategori: } \\
\text {-TM (total skor <14) } \\
\text { utilitas dan }\end{array}$ & 6 & CM (total skor 14-22) \\
& & & -SM (total skor >22) \\
\hline
\end{tabular}

2. Analisis hubungan dengan menggunakan analisis tabulasi silang (crosstabs) dan uji chisquare untuk menjelaskan hubungan antara karakteristik individu/rumah tangga dengan motivasi pembelian rumah. Karakteristik rumah tangga/ individu yang diamati pada penilitian ini antara lain: 1) tingkat pendidikan, 2) tingkat penghasilan, 3) usia, 4) jenis pekerjaan, 5) jumlah anggota keluarga dan 6) tipe rumah.

\section{HASIL DAN PEMBAHASAN}

\section{Karakteristik Responden}

Penelitian ini menggunakan sampel sebanyak 91 responden dari penghuni perumahan yang berada di daerah pinggiran kota Surakarta. Karakteristik responden dapat dilihat pada Gambar 3.

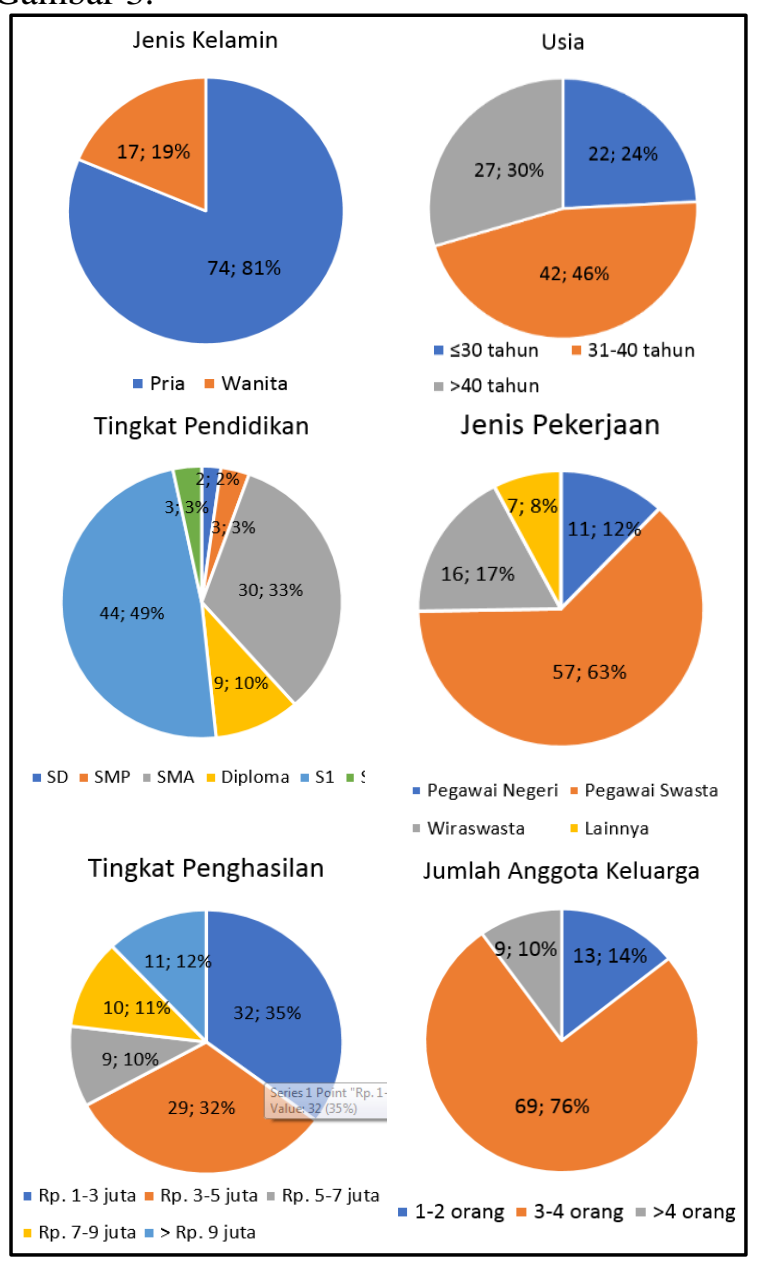

Gambar 3. Karakteristik Responden 
Dari keseluruhan responden, sebagian besar responden mempunyai jenis kelamin laki-laki dengan jumlah sebanyak 74 orang (81\%), sedangkan jumlah responden perempuan sebanyak 17 orang (19\%). Berdasarkan kelompok usia, responden paling banyak berada di kelompok usia 31-40 tahun, yaitu sebanyak 42 orang (46\%), kemudian diikuti dengan responden dengan kelompok usia 41-50 tahun sebanyak 27 orang $(27 \%)$ dan kelompok usia $\leq 30$ tahun sebanyak 22 orang $(24 \%)$.

Berdasarkan tabel 2, tingkat pendidikan di dominasi oleh tingkat pendidikan S1 sebanyak 44 orang (49\%) dan SMA sebanyak 30 orang (33\%). Sedangkan jika menurut jenis pekerjaan, sebagian besar responden dalam penelitian ini bahkan lebih dari separuh mempunyai pekerjaan sebagai pegawai swasta yaitu sebanyak 57 orang atau $63 \%$ dari keseluruhan responden. Selanjutnya terbanyak kedua adalah responden dengan jenis pekerjaan wiraswasta sebanyak 16 orang $(17 \%)$, kemudian pegawai negeri sipil (PNS) sebanyak 11 orang (12\%), dan lainnya (ibu rumah tangga, profesi, mahasiswa) sebanyak 7 orang (8\%),

Berdasarkan pada tingkat penghasilan keluarga, responden mempunyai distribusi yang cukup merata pada setiap tingkatan penghasilan keluarga. Dari hasil survei dapat diketahui bahwa tingkatan penghasilan keluarga sebagian besar responden berada pada Rp. 1.000.000 Rp.3.000.000 sebanyak 32 orang (35\%), dan Rp. 3.000.000 - Rp. 5.000 .000 sebanyak 29 orang $(32 \%)$. Kemudian selanjutnya diikuti dengan responden yang mempunyai tingkat penghasilan keluarga sebesar > Rp. 9.000.000 sebanyak 11 orang (12\%), Rp. 7.000.000 - Rp. 9.000 .000 sebanyak 10 orang (11\%), dan Rp. $5.000 .000-$ Rp. 7.000 .000 sebanyak 9 orang (10\%).

Bila dilihat dari jumlah anggota keluarga, sebagian besar responden mempunyai jumlah keluarga yang tinggal dalam satu rumah sebanyak 3-4 orang dengan jumlah 69 responden (76\%), selanjutnya responden dengan jumlah anggota keluarga 1-2 orang sebanyak 13 orang (14\%) dan responden dengan jumlah anggota keluarga $>4$ orang sebanyak 9 orang (10\%).

\section{Preferensi Pemilihan Perumahan Berdasarkan Motivasi Pembelian Rumah}

Analisis yang pertama dilakukan adalah analisis preferensi pemilihan perumahan berdasarkan motivasi pembelian rumah. Analisis dilakukan dengan menghitung skor total dari tiap faktor berdasarkan indikator-indikatornya melalui pertanyaaan yang diajukan kepada responden, kemudian skor tersebut diklasifikasikan berdasarkan tingkat pengaruh faktor. Tingkat atau kategori pengaruh faktor-faktor yang mempengaruhi pemilihan perumahan dibagi menjadi tiga kelas berdasarkan nilainya, yaitu: 1) Tidak mempengaruhi, 2) Cukup mempengaruhi dan 3) Sangat mempengaruhi. Semakin besar nilai rata-rata dari faktor (mendekati 3), maka faktor tersebut semakin mempengaruhi sebagai pertimbangan dalam pemilihan perumahan.

\section{a. Faktor Pembiayaan Rumah}

Faktor pembiayaan rumah merupakan faktor yang sangat mempengaruhi masyarakat dalam memilih perumahan, baik itu pada masyarakat yang membeli rumah dengan tujuan untuk konsumsi sebagai tempat tinggal ataupun untuk tujuan investasi. Hal ini didapat dilihat pada nilai rata-rata pengaruh faktor pembiayaan rumah pada masing-masing motif pembelian (tabel 3).

Tabel 7. Tingkat Pengaruh Faktor Pembiayaan Rumah dalam Pemilihan Perumahan

\begin{tabular}{|c|c|r|r|r|r|r|}
\hline \multirow{2}{*}{ Motif } & \multicolumn{2}{|c|}{$\begin{array}{c}\text { Kategori Pengaruh Faktor } \\
\text { Pembiayaan Rumah }\end{array}$} & \multirow{2}{*}{$\begin{array}{c}\text { Jumlah } \\
\text { Total }\end{array}$} & $\begin{array}{c}\text { Rata- } \\
\text { rata }\end{array}$ \\
\cline { 2 - 6 } & SM & CM & TM & & \\
\hline \multirow{2}{*}{ Konsumsi } & Jml & 39 & 10 & 1 & 50 & \multirow{2}{*}{2,76} \\
\cline { 2 - 6 } & $\%$ & 78,0 & 20,0 & 2,0 & 100,0 & \\
\hline \multirow{3}{*}{ Investasi } & Jml & 29 & 8 & 4 & 41 & \multirow{2}{*}{2,61} \\
\cline { 2 - 6 } & $\%$ & 70,7 & 19,5 & 9,8 & 100,0 & \\
\hline
\end{tabular}

Keterangan: SM (Sangat Mempengaruhi), CM (Cukup Mempengaruhi, TM (Tidak Mempengaruhi)

Pada motif pembelian rumah untuk konsumsi nilai rata-rata pengaruh faktor pembiayaan rumah mencapai 2,76, dengan sebagian besar masyarakat $(78,0 \%)$ menganggap faktor ini sangat berpengaruh. Sama halnya dengan motif pembelian rumah untuk konsumsi, pada motif pembelian rumah sebagai investasi, faktor pembiayaan rumah juga menjadi faktor yang dianggap sangat mempengaruhi dalam pemilihan rumah, yaitu nilai rata-rata pengaruh mencapai 2,61 dengan sebagian besar masyarakat $(70,7 \%)$ menempatkan faktor ini sebagai faktor yang sangat berpengaruh.

Pada motif pembelian rumah untuk konsumsi, alasan faktor pembiayaan rumah sangat berpengaruh dalam memilih perumahan adalah karena keputusan dalam membeli rumah adalah suatu keputusan besar dalam sebuah rumah tangga, oleh karena itu faktor pembiayaan rumah yang di dalamnya termasuk harga rumah dan sistem pembayaran harus benar-benar dipertimbangkan. Hal ini terutama terjadi pada konsumen yang merupakan masyarakat berpenghasilan rendah yang pada umumnya membeli rumah dengan cara melalui kredit. 
Konsumen atau masyarakat perumahan akan menyesuaikan apakah pembiayaan rumah sesuai dengan kemampuannya dalam melakukan pembelian rumah, sehingga dalam pembayaran rumah tidak membuat konsumen merasa kesulitan. Hal ini sesuai dengan yang diungkapkan Ehwan (2008) bahwa penjualan rumah perlu didukung oleh sistem pembiayaan yang dapat menarik masyarakat untuk membeli rumah. Konsumen akan lebih berminat pada rumah yang dijual dengan harga terjangkau dan sesuai dengan kondisi sosial ekonomi masyarakat.

\section{b. Faktor Kondisi Fisik Rumah}

Faktor kondisi fisik rumah pada kedua motif pembelian rumah sama-sama sangat mempengaruhi dalam pemilihan perumahan. Tetapi apabila dilihat berdasarkan nilai rata-rata pengaruhnya, faktor kondisi fisik rumah lebih menjadi faktor yang dipertimbangkan oleh rumah tangga yang membeli rumah untuk motif investasi daripada yang membeli rumah untuk konsumsi. Dari hasil perhitungan (tabel 4) dapat dilihat nilai rata-rata pengaruh pada motif investasi adalah sebesar 2,83, sedangkan nilai rata-rata pengaruh pada motif konsumsi 2,62.

Tabel 8. Tingkat Pengaruh Faktor Kondisi Fisik Rumah dalam Pemilihan Perumahan

\begin{tabular}{|c|c|r|r|r|r|r|}
\hline \multirow{2}{*}{ Motif } & \multicolumn{3}{|c|}{$\begin{array}{c}\text { Kategori Pengaruh Faktor } \\
\text { Kondisi Fisik Rumah }\end{array}$} & \multirow{2}{*}{$\begin{array}{c}\text { Jumlah } \\
\text { Total }\end{array}$} & $\begin{array}{c}\text { Rata- } \\
\text { rata }\end{array}$ \\
\cline { 3 - 7 } & SM & CM & TM & & \\
\hline \multirow{3}{*}{ Konsumsi } & Jml & 32 & 17 & 1 & 50 & \multirow{2}{*}{2,62} \\
\cline { 2 - 6 } & $\%$ & 64,0 & 34,0 & 2,0 & 100,0 & \\
\hline \multirow{3}{*}{ Investasi } & Jml & 35 & 5 & 1 & 41 & \multirow{2}{*}{2,83} \\
\cline { 2 - 6 } & $\%$ & 85,4 & 12,2 & 2,4 & 100,0 & \\
\hline
\end{tabular}

Keterangan: SM (Sangat Mempengaruhi), CM (Cukup Mempengaruhi, TM (Tidak Mempengaruhi)

Menurut perhitungan (tabel 4), pada masyarakat yang membeli rumah untuk konsumsi, faktor kondisi fisik rumah dianggap sebagai faktor yang sangat berpengaruh, tetapi apabila dilihat dari proporsinya hanya $64 \%$ dari konsumen yang membeli rumah untuk konsumsi yang menganggap faktor ini sebagai bahan pertimbangan dalam membeli rumah. Hal ini disebabkan karena pada konsumen yang membeli rumah untuk konsumsi menganggap bahwa rumah yang dibeli adalah untuk ditempati dalam waktu yang lama, sehingga kondisi fisik rumah dapat ditingkatkan lagi sepanjang rumah itu ditinggali.

Sementara, berdasarkan dari hasil perhitungan, dapat dilihat bahwa sebagian besar atau $85,4 \%$ dari masyarakat yang membeli rumah untuk investasi memandang bahwa faktor kondisi fisik rumah menjadi hal yang sangat dipertimbangkan dalam memilih perumahan. Hal ini disebabkan karena rumah sebagai barang investasi akan mempunyai nilai yang lebih tinggi jika kondisi fisik rumahnya bagus. Selain itu juga, apabila kondisi fisik rumah bagus, maka dalam melakukan pemasaran untuk penjualan atau penyewaan rumah akan jauh lebih mudah. Selain itu dengan kondisi fisik rumah yang bagus, nilai jual atau sewa dari rumah itu juga semakin tinggi.

Dari besaran angka rata-rata pengaruh pada tiap motivasi, maka dapat disimpulkan bahwa faktor kondisi fisik rumah lebih dipertimbangkan sebagai faktor pemilihan rumah oleh konsumen yang membeli perumahan untuk investasi daripada oleh konsumen yang membeli untuk konsumsi.

\section{c. Faktor Lokasi dan Aksesibilitas}

Faktor lokasi dan aksesibilitas menjadi faktor yang sangat mempengaruhi keputusan dalam pemilihan perumahan di pinggiran Kota Surakarta, baik itu berdasarkan motif pembelian rumah untuk konsumsi maupun untuk investasi. Hal ini didapat dilihat pada nilai rata-rata pengaruh faktor lokasi dan aksesibilitas pada masing-masing motif pembelian (tabel 4). Pada motif pembelian rumah untuk konsumsi, nilai rata-rata pengaruh faktor lokasi dan aksesibilitas mencapai 2,76, dengan sebagian besar konsumen $(76,0 \%)$ menganggap faktor ini sangat berpengaruh. Sama halnya dengan motif pembelian rumah untuk konsumsi, pada motif pembelian rumah sebagai investasi faktor lokasi dan aksesibilitas juga menjadi faktor yang dianggap sangat mempengaruhi dalam pemilihan rumah, yaitu nilai rata-rata pengaruh mencapai 2,80 dengan sebagian besar konsumen $(82,9 \%)$ menempatkan faktor ini sebagai faktor yang sangat berpengaruh.

Tabel 9. Tingkat Pengaruh Faktor Lokasi dan Aksesibilitas dalam Pemilihan Perumahan

\begin{tabular}{|c|c|r|r|r|r|l|}
\hline \multirow{2}{*}{ Motif } & \multicolumn{2}{|c|}{$\begin{array}{c}\text { Kategori Pengaruh Faktor } \\
\text { Lokasi dan Aksesibilitas }\end{array}$} & \multirow{2}{*}{$\begin{array}{c}\text { Jumlah } \\
\text { Total }\end{array}$} & $\begin{array}{c}\text { Rata- } \\
\text { rata }\end{array}$ \\
\cline { 2 - 6 } & SM & CM & TM & & \\
\hline \multirow{3}{*}{ Konsumsi } & Jml & 38 & 12 & 0 & 50 & \multirow{2}{*}{2,76} \\
\cline { 2 - 6 } & $\%$ & 76,0 & 24,0 & 0,0 & 100,0 & \\
\hline \multirow{3}{*}{ Investasi } & Jml & 34 & 6 & 1 & 41 & \multirow{2}{*}{2,80} \\
\cline { 2 - 6 } & $\%$ & 82,9 & 14,6 & 2,4 & 100,0 & \\
\hline
\end{tabular}

Keterangan: SM (Sangat Mempengaruhi), CM (Cukup Mempengaruhi, TM (Tidak Mempengaruhi)

Bagi konsumen yang membeli rumah untuk konsumsi, tentunya sangat mempertimbangkan faktor lokasi dan aksesibilitas dalam memilih 
perumahan. Lokasi perumahan yang strategis, misalnya terletak dekat dengan pusat-pusat kegiatan dan fasilitas pelayanan umum, maka memudahkan penghuninya untuk mendapatkan berbagai layanan yang dibutuhkan dengan mudah. Selain itu dengan aksesibilitas yang baik, maka dalam melakukan pergerakan untuk menuju ke pusat kegiatan juga akan semakin mudah dan juga murah, sehingga dapat memperkecil pengeluaran untuk biaya transportasi. Sedangkan bagi konsumen yang membeli rumah sebagai barang investasi, faktor lokasi dan aksesibilitas sangat dipertimbangkan karena dengan letak lokasi perumahan yang strategis dan aksesibilitas yang baik, maka akan mempunyai prospek yang lebih baik untuk meningkatkan nilai investasi dari perumahan. Lokasi perumahan yang mempunyai letak dengan pusat-pusat kegiatan dan memiliki aksesibilitas yang baik menuju ke pusat-pusat kegiatan tersebut, mempunyai potensi perkembangan lebih cepat. Lokasi perumahan dan sekitarnya yang berkembang dengan cepat akan membuat nilai rumah sebagai barang investasi pun menjadi lebih tinggi dan lebih mudah pula untuk dipasarkan. Hal ini sesuai dengan yang dikatakan oleh Lusht (1997), yang menyatakan bahwa salah satu prinsip dari penentuan nilai properti adalah aksesibilitas menuju properti tersebut. Semakin banyak aksesnya, maka nilai properti akan semakin tinggi. Sebaliknya, semakin sedikit akses maka akan semakin rendah nilai properti. Dengan nilai jual yang lebih tinggi dan kemudahan pemasaran maka pemilik rumah sebagai investor lebih cepat untuk memperoleh keuntungan. Demikian juga apabila rumah tersebut diinvestasikan untuk disewakan, maka nilai sewa rumah juga akan lebih tinggi dan juga masyarakat yang berminat untuk menyewa rumah tersebut juga lebih banyak.

\section{d. Faktor Kondisi Fisik Lingkungan}

Faktor kondisi fisik lingkungan pada kedua motif pembelian rumah sama-sama mempunyai kategori pengaruh dengan tingkat sangat mempengaruhi dalam pemilihan perumahan. Tetapi apabila dilihat berdasarkan nilai rata-rata pengaruhnya, faktor kondisi fisik lingkungan lebih menjadi faktor yang dipertimbangkan oleh konsumen atau masyarakat yang membeli rumah untuk motif konsumsi daripada yang membeli rumah untuk investasi. Dari hasil perhitungan (tabel 6) dapat dilihat nilai rata-rata pengaruh pada motif pembelian untuk konsumsi adalah sebesar 2,84, sedangkan nilai rata-rata pengaruh pada motif investasi sebesar 2,78. Dari besaran angka rata-rata pengaruh pada tiap motivasi, maka dapat disimpulkan bahwa faktor kondisi fisik rumah lebih dipertimbangkan sebagai faktor pemilihan rumah oleh konsumen yang membeli perumahan untuk konsumsi daripada oleh konsumen yang membeli untuk tujuan investasi.

Tabel 10. Tingkat Pengaruh Faktor Kondisi Fisik Lingkungan dalam Pemilihan Perumahan

\begin{tabular}{|c|c|r|r|r|r|r|}
\hline \multicolumn{2}{|c|}{ Motif } & \multicolumn{3}{|c|}{$\begin{array}{c}\text { Kategori Pengaruh Faktor } \\
\text { Kondisi Fisik Lingkungan }\end{array}$} & \multirow{2}{*}{$\begin{array}{c}\text { Jumlah } \\
\text { Total }\end{array}$} & $\begin{array}{c}\text { Rata- } \\
\text { rata }\end{array}$ \\
\cline { 2 - 7 } & SM & CM & TM & & \\
\hline \multirow{3}{*}{ Konsumsi } & Jml & 42 & 8 & 0 & 50 & \multirow{2}{*}{2,84} \\
\cline { 2 - 7 } & $\%$ & 84,0 & 16,0 & 0,0 & 100,0 & \\
\hline \multirow{3}{*}{ Investasi } & $\mathbf{J m l}$ & 32 & 9 & 0 & 41 & \multirow{2}{*}{2,78} \\
\cline { 2 - 7 } & $\%$ & 78,0 & 22,0 & 0,0 & 100,0 & \\
\hline
\end{tabular}

Keterangan: SM (Sangat Mempengaruhi), CM (Cukup Mempengaruhi, TM (Tidak Mempengaruhi)

Pada masyarakat yang membeli perumahan untuk tujuan konsumsi, faktor kondisi fisik lingkungan menjadi faktor yang sangat dipertimbangkan, hal ini terbukti dari analisis yang dilakukan, yaitu hampir seluruh masyarakat (84\%) menetapkan faktor ini menjadi faktor yang sangat dipertimbangkan dan tidak ada yang menganggap faktor ini sebagai faktor yang tidak mempengaruhi. Faktor ini menjadi sangat penting karena sangat erat kaitannya dengan tingkat kenyamanan dalam bermukim. Masyarakat yang bermukim pada suatu perumahan pastinya akan mengharapkan suatu lingkungan perumahan yang nyaman untuk ditinggali, dan kenyamanan itu dapat terwujud apabila kondisi lingkungan perumahan yang ditempatinya mempunyai kualitas yang baik, seperti bebas dari polusi, kebersihan yang terjaga, bebas dari ancaman bencana, terdapat ruang terbuka hijau dan lainlain. Selain kenyamanan, dengan tinggal di perumahan yang mempunyai kondisi fisik lingkungan yang bagus akan membuat kondisi kesehatan penghuninya juga lebih terjaga.

Sama halnya dengan masyarakat yang membeli rumah untuk konsumsi, masyarakat yang membeli rumah untuk investasi juga menganggap faktor kondisi fisik lingkungan menjadi faktor yang sangat mempengaruhi dalam pemilihan perumahan. Karena perumahan dengan kondisi fisik lingkungan yang baik akan meningkatkan nilai dari rumah dan membuat harga rumah akan menjadi lebih tinggi jika dijual, selain itu dengan kondisi lingkungan yang bebas dari ancaman bencana dan polusi, maka investasi yang dilakukan juga lebih aman tanpa ada resiko rumah yang menjadi barang investasi mengalami kerusakan yang akhirnya menimbulkan kerugian dalam berinvestasi. 


\section{e. Faktor Kondisi Sosial Lingkungan}

Faktor kondisi sosial lingkungan mempunyai tingkat pengaruh yang hampir sama sebagai faktor yang dipertimbangkan dalam memilih perumahan, baik dari motif membeli rumah untuk konsumsi maupun investasi. Faktor kondisi sosial lingkungan kurang menjadi pertimbangan dalam pemilihan perumahan..

Berdasarkan hasil perhitungan (tabel 6), pada konsumen yang membeli rumah untuk konsumsi, faktor kondisi sosial mempunyai nilai rata-rata tingkat pengaruh sebesar 2,16, sedangkan pada konsumen yang membeli rumah untuk investasi, nilai rata-rata tingkat pengaruh faktor kondisi sosial lingkungan mempunyai nilai yang lebih kecil yaitu 2,07. Apabila dimasukkan dalam kategori tingkat pengaruh, maka faktor kondisi sosial lingkungan termasuk dalam kategori cukup mempengaruhi sebagai faktor dalam pemilihan perumahan.

Tabel 11. Tingkat Pengaruh Faktor Kondisi Sosial Lingkungan dalam Pemilihan Perumahan

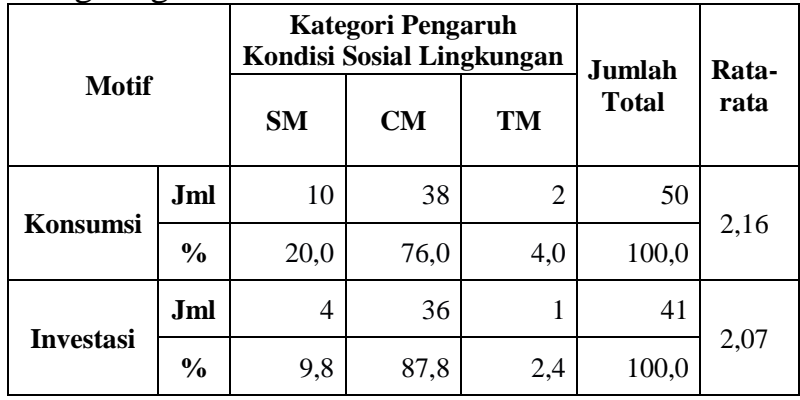

Keterangan: SM (Sangat Mempengaruhi), CM (Cukup Mempengaruhi, TM (Tidak Mempengaruhi)

Pada motif pembelian rumah untuk pemenuhan konsumsi, faktor kondisi sosial lingkungan kurang menjadi pertimbangan dalam pemilihan perumahan. Berdasarkan pada motif ini hanya sebagian kecil atau $20 \%$ dari masyarakat yang menganggap faktor ini menjadi faktor yang sangat mempengaruhi dalam pemilihan perumahan. Hal ini terjadi karena pada sebagian masyarakat yang menempati perumahan merupakan masyarakat pendatang atau bukan warga asli sekitar, sehingga masyarakat perumahan merupakan masyarakat yang heterogen yang mempunyai keragaman baik dari kelas sosial maupun ekonominya. Apabila harus mencari perumahan yang mempunyai kondisi sosial atau kondisi ekonomi yang homogen dalam suatu perumahan, maka itu merupakan hal sulit untuk dilakukan. Indikator yang lain seperti kedekatan dengan kerabat/keluarga, persamaan status sosial dengan tetangga dan persamaan status ekonomi dengan tetangga tidak dianggap penting dalam pertimbangan memilih perumahan. Hal ini karena pada umumnya masyarakat modern saat ini tidak terlalu memperhatikan perbedaaan status dengan tetangganya baik itu status sosial dan ekonomi dalam bermukim, dan hal itu merupakan urusan pribadi dari masing-masing individu.

Pada motif pembelian rumah untuk investasi, faktor kondisi sosial lingkungan menjadi faktor yang hanya cukup berpengaruh terhadap pemilihan perumahan, hal ini dapat dapat dilihat bahwa hanya sebanyak 9,8\% konsumen yang membeli rumah untuk investasi yang mempertimbangkan faktor ini sebagai alasan untuk membeli rumah. Hal ini disebabkan karena pada konsumen yang membeli rumah sebagai sarana investasi beranggapan bahwa mereka hanya sementara atau tidak selamanya untuk tinggal di rumah tersebut, bahkan tidak sedikit pula yang tidak menempati rumah tersebut atau rumah hanya dijadikan sarana sebagai tempat persinggahan saja, sehingga dalam hal ini kondisi sosial lingkungan perumahan tidak terlalu dianggap penting dalam keputusan memilih perumahan.

\section{f. Faktor Ketersediaan Fasilitas dan Utilitas}

Faktor ketersediaan fasilitas dan utilitas pada kedua motif pembelian rumah sama-sama mempunyai kategori pengaruh pada tingkat sangat mempengaruhi dalam pemilihan perumahan. Tetapi apabila dilihat berdasarkan nilai rata-rata pengaruhnya, faktor kondisi ketersediaan fasilitas dan utilitas lebih menjadi faktor yang dipertimbangkan oleh konsumen atau masyarakat yang membeli rumah untuk motif konsumsi daripada yang membeli rumah untuk tujuan investasi. Dari hasil perhitungan (tabel 8) dapat dilihat nilai rata-rata pengaruh pada motif kebutuhan dasar adalah sebesar 2,68, sedangkan nilai rata-rata pengaruh pada motif investasi sebesar 2,59.

Tabel 12. Tingkat Pengaruh Faktor Ketersediaan Fasilitas dan Utilitas dalam Pemilihan Perumahan

\begin{tabular}{|c|c|r|r|r|r|r|}
\hline \multirow{2}{*}{ Motif } & \multicolumn{3}{|c|}{$\begin{array}{l}\text { Kategori Pengaruh Faktor } \\
\text { Ketersediaan Fasilitas dan } \\
\text { Utilitas }\end{array}$} & \multirow{2}{*}{$\begin{array}{c}\text { Jumlah } \\
\text { Total }\end{array}$} & $\begin{array}{c}\text { Rata- } \\
\text { rata }\end{array}$ \\
\cline { 2 - 6 } & & SM & CM & TM & & \\
\hline \multirow{2}{*}{ Konsumsi } & Jml & 34 & 16 & 0 & 50 & \multirow{2}{*}{2,68} \\
\cline { 2 - 6 } & $\%$ & 68,0 & 32,0 & 0,0 & 100,0 & \\
\hline \multirow{3}{*}{ Investasi } & Jml & 25 & 15 & 1 & 41 & \multirow{2}{*}{2,59} \\
\cline { 2 - 6 } & $\%$ & 61,0 & 36,6 & 2,4 & 100,0 & \\
\hline
\end{tabular}

Keterangan: SM (Sangat Mempengaruhi), CM (Cukup Mempengaruhi, TM (Tidak Mempengaruhi)

Pada motif pembelian rumah untuk konsumsi, faktor ketersediaan fasilitas dan utilitas menjadi faktor yang sangat mempengaruhi dalam memilih perumahan. Hal ini dapat dilihat pada 
hasil perhitungan (tabel 8) bahwa sebanyak 68\% dari konsumen yang membeli properti dengan tujuan memenuhi kebutuhan dasar menganggap faktor ketersediaan fasilitas dan utilitas menjadi faktor yang sangat mempengaruhi dalam pertimbangan memilih perumahan. Dengan motif membeli untuk konsumsi, maka konsumen akan menempati rumah tersebut untuk jangka waktu yang lama, sehingga ketersediaan fasilitas dan utilitas menjadi hal yang sangat penting dalam menunjang kebutuhan hidup dan bermukim di perumahan tersebut.

Sama halnya dengan masyarakat yang membeli rumah dengan motif untuk memenuhi kebutuhan dasar, masyarakat yang membeli untuk tujuan investasi juga menganggap faktor ketersediaan fasilitas dan utilitas sebagai faktor yang sangat dipertimbangkan dalam memilih perumahan. Dengan fasilitas dan utilitas yang lengkap dan baik maka akan membuat rumah yang dijadikan untuk investasi lebih tinggi nilainya dan juga akan menarik minat para pembeli atau penyewa. Hal ini sesuai dengan yang dinyatakan oleh Appraisal Institute (2001) bahwa salah satu karakteristik yang mempengaruhi nilai dari properti adalah fasilitas yang ada, seperti sanitasi, jaringan air minum, listrik dan telepon.

\section{Analisis Peringkat Faktor-Faktor Pemilihan Perumahan berdasarkan Motif Pembelian Rumah}

Berdasarkan nilai rata-rata tingkat pengaruh, preferensi pemilihan rumah pada konsumen yang membeli rumah untuk konsumsi berbeda dengan konsumen yang membeli rumah untuk investasi.

Menurut konsumen yang membeli rumah berdasarkan motivasi konsumsi, urutan atau peringkat faktor-faktor yang mempengaruhi pemilihan perumahan adalah sebagai berikut: 1) faktor kondisi fisik lingkungan, 2) faktor pembiayaan rumah, 3) faktor lokasi dan aksesibilitas, 4) faktor ketersediaan fasilitas dan utilitas, 5) faktor kondisi fisik rumah dan 6) faktor kondisi sosial lingkungan. Sedangkan untuk kelompok konsumen atau masyarakat perumahan yang mempunyai motif pembelian rumah untuk tujuan investasi, urutan atau peringkat faktorfaktor yang mempengaruhi pemilihan rumah adalah sebagai berikut: 1) faktor kondisi fisik rumah, 2) faktor lokasi dan aksesibilitas, 3) faktor kondisi fisik lingkungan, 4) faktor pembiayaan rumah, 5) faktor ketersediaan fasilitas dan utilitas, dan 6) faktor kondisi sosial lingkungan. Nilai ratarata pengaruh dari faktor pemilihan perumahan dapat dilihat pada gambar 2 .

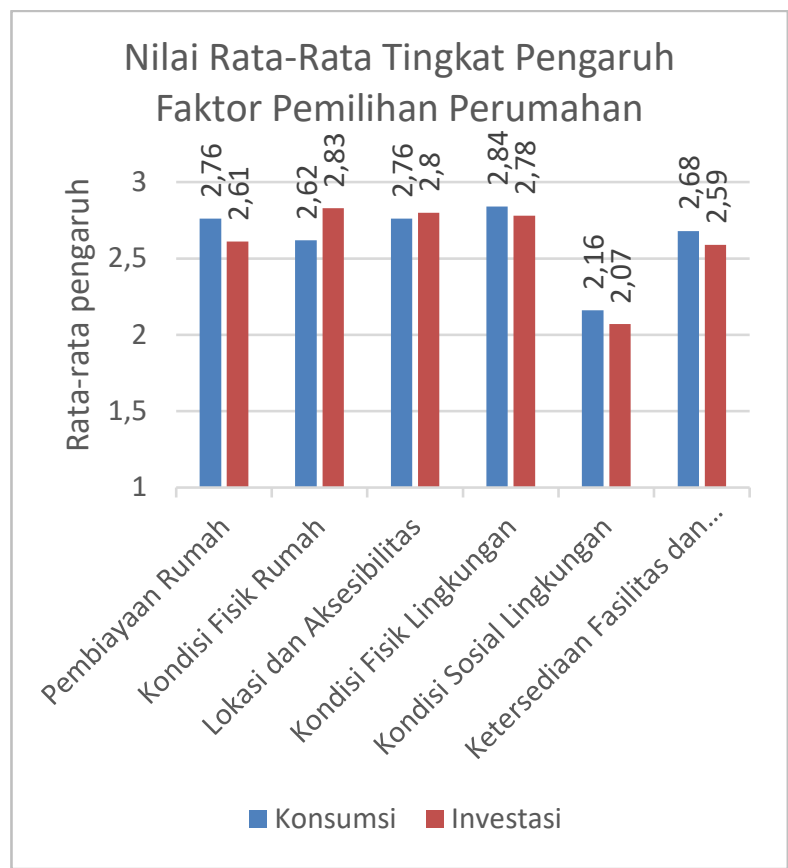

Gambar 2. Nilai Rata-Rata Tingkat Pengaruh Faktor Pemilihan Perumahan

Berdasarkan analisis dari perhitungan faktor-faktor yang mempengaruhi pemilihan perumahan di pinggiran kota Surakarta, didapatkan temuan bahwa konsumen yang membeli rumah untuk tujuan konsumsi mempunyai preferensi yang berbeda apabila dibandingkan dengan konsumen yang membeli rumah untuk investasi. Bagi konsumen yang membeli rumah untuk konsumsi, faktor kondisi fisik lingkungan merupakan faktor yang paling mempengaruhi dalam pemilihan perumahan. Hal ini disebabkan pada rumah tangga yang membeli rumah untuk konsumsi lebih memprioritaskan kenyamanan dalam bertempat tinggal yang didukung oleh faktor kondisi fisik lingkungan. Kenyamanan dalam bertempat tinggal sangat penting bagi konsumen yang membeli rumah untuk konsumsi karena mereka akan menempati perumahan tersebut dalam waktu yang lama. Faktor kedua yang paling mempengaruhi dalam pemilihan rumah adalah faktor pembiayaan rumah. Faktor pembiayaan rumah ini dianggap sangat penting dalam mempengaruhi pemilihan perumahan karena berkaitan dengan kemampuan konsumen dalam membeli perumahan tersebut. Konsumen akan mempertimbangkan bagaimana pembiayaan rumah tersebut dalam hal ini harga rumah, uang muka, besarnya angsuran dan lama angsuran, apakah sesuai dengan kemampuan konsumen, sehingga dalam melakukan memilih rumah tersebut konsumen tidak mempunyai kesulitan dalam pembelian dan pembayarannya. Berdasarkan prioritas faktor tersebut maka dapat disimpulkan bahwa preferensi konsumen yang 
membeli rumah untuk konsumsi adalah perumahan yang memiliki kondisi fisik lingkungan yang nyaman dan mempunyai sistem pembiayaan rumah yang tidak menyulitkan.

Prioritas yang berbeda terjadi pada konsumen yang membeli rumah untuk investasi terhadap faktor yang mempengaruhi pemilihan perumahan Bagi konsumen yang membeli rumah dengan motif investasi, faktor kondisi fisik rumah merupakan faktor yang menjadi prioritas sebagai pertimbangan dalam memilih perumahan. Kondisi fisik rumah menjadi faktor yang sangat penting karena sangat berpengaruh terhadap harga rumah. Dengan mengetahui kondisi fisik rumah yang dibeli maka dapat diperkirakan pula nilai keuntungan atau capital gain yang akan didapatkan bila rumah tersebut dijual kembali. Faktor kedua yang menjadi prioritas pemilihan perumahan adalah faktor lokasi dan aksesibilitas. Faktor lokasi dan aksesibilitas ini sangat penting bagi investor karena sangat berpengaruh terhadap nilai atau harga rumah. Dengan lokasi perumahan yang strategis dan aksesibilitas yang tinggi maka kawasan perumahan akan berkembang dengan cepat dan harga jual rumah akan semakin meningkat sehingga keuntungan yang diharapkan dapat tercapai. Berdasarkan prioritas faktor tersebut maka dapat disimpulkan bahwa preferensi konsumen yang membeli rumah untuk investasi adalah perumahan yang memiliki kondisi fisik yang bagus dan mempunyai lokasi yang strategis serta aksesibilitas yang tinggi.

\section{Analisis Hubungan Karakteristik Individu/Rumah Tangga dengan Motivasi Pembelian Rumah}

Berdasarkan analisis sebelumnya tentang preferensi pemilihan perumahan berdasarkan dengan motif pembelian rumah, dapat diasumsikan bahwa tiap-tiap individu atau rumah tangga mempunyai karakteristik yang berbedabeda dan mempengaruhi motivasi dalam membeli rumah, baik itu untuk konsumsi atau untuk berinvestasi. Untuk itu perlu dilakukan analisis untuk mengetahui apakah memang ada hubungan antara karakteristik individu dan rumah tangga dengan motivasi dalam membeli rumah.

Untuk mengetahui ada tidaknya hubungan variabel karakteristik individu dan rumah tangga dengan motif pembelian rumah di pinggiran Kota Surakarta, maka perlu dilakukan analisis bivariat antar dua variabel. Dalam penelitian ini analisis yang dilakukan adalah dengan menggunakan analisis tabulasi silang (Crosstabs) untuk mengetahui distribusi karakteristik individu dan rumah tangga berdasarkan motif pembelian rumah, sedangkan untuk mengetahui ada tidaknya hubungan antar variabel dengan menggunakan analisis Chi-Square dengan acuan hipotesis dan pengambilan keputusan dengan melihat angka probabilitas hasil perhitungan, yaitu:

- $\mathrm{H}_{0}$ : Tidak terdapat hubungan antara karakteristik individu/rumah tangga terhadap motif pembelian rumah

- $\mathrm{H}_{1}$ : Terdapat hubungan antara karakteristik individu/rumah tangga terhadap motif pembelian rumah.

- Nilai signifikansi > 0,005, maka $\mathrm{H}_{0}$ diterima, berarti tidak terdapat hubungan antar variabel

- Nilai signifikansi < 0,005, maka $\mathrm{H}_{0}$ ditolak, berarti terdapat hubungan antar variabel

\section{a. Tingkat Pendidikan}

Apabila dilihat berdasarkan distribusinya, pada rumah tangga perumahan di pinggiran Kota Surakarta yang membeli rumah untuk investasi, sebagian besar $(82,9 \%)$, merupakan rumah tangga yang kepala keluarganya mempunyai tingkat pendidikan yang tinggi. Sedangkan pada rumah tangga yang membeli rumah untuk konsumsi, distribusi tingkat pendidikan kepala keluarganya hampir sama antara yang berpendidikan dasarmenengah $(56 \%)$ dengan yang berpendidikan tinggi (44\%). Dari hasil tabulasi silang juga diketahui bahwa individu/rumah tangga yang membeli rumah untuk tujuan investasi cenderung mempunyai tingkat pendidikan yang tinggi

Tabel 13. Uji Chi-Square Tingkat Pendidikan dengan Motif Pembelian Rumah

\begin{tabular}{|l|l|r|r|r|r|}
\hline \multicolumn{4}{|c|}{ Pendidikan * Motif Crosstabulation } \\
\cline { 3 - 5 } \multicolumn{2}{|c|}{} & \multicolumn{2}{c|}{ Motif } & \multirow{2}{*}{ Total } \\
\hline \multirow{3}{*}{ Pendidikan } & Dasar- & jml & 7 & 28 & 35 \\
\cline { 3 - 6 } & Menengah & $\%$ & $17,1 \%$ & $56,0 \%$ & $38,5 \%$ \\
\cline { 3 - 6 } & \multirow{2}{*}{ Tinggi } & jml & 34 & 22 & 56 \\
\cline { 3 - 6 } & & $\%$ & $82,9 \%$ & $44,0 \%$ & $61,5 \%$ \\
\hline \multirow{2}{*}{ Total } & jml & 41 & 50 & 91 \\
\cline { 3 - 6 } & & $\%$ & $100 \%$ & $100 \%$ & $100 \%$ \\
\hline
\end{tabular}

\begin{tabular}{|l|r|r|r|}
\hline & \multicolumn{1}{|c|}{ Value } & df & $\begin{array}{c}\text { Asymp. Sig. } \\
\text { (2-sided) }\end{array}$ \\
\hline Pearson Chi-Square & $14,422^{\mathrm{a}}$ & 1 & 0,000 \\
\hline Likelihood Ratio & 15,192 & 1 & 0,000 \\
\hline Linear-by-Linear Association & 14,264 & 1 & 0,000 \\
\hline N of Valid Cases & 91 & & \\
\hline
\end{tabular}

Berdasarkan hasil uji Chi-Square, diperoleh hasil yang signifikan dengan nilai signifikansi sebesar 0,000 . Nilai ini lebih kecil dari $\alpha(0,05)$, sehingga $\mathrm{H}_{0}$ ditolak. Hal ini menunjukkan bahwa terdapat hubungan yang kuat antara tingkat pendidikan dengan motif dalam membeli rumah.

Dengan demikian dapat disimpulkan bahwa dengan tingkat pendidikan yang tinggi, individu akan mempunyai mempunyai motif untuk 
melakukan investasi perumahan. Hal ini sesuai dengan yang diungkapkan oleh Jain dan Mandot (2012) bahwa semakin tinggi pendidikan maka mempengaruhi dalam menentukan keputusan untuk berinvestasi. Kesimpulan yang sama juga diungkapkan oleh Rahmawati, dkk (2015) dalam penelitiannya tentang faktor yang mempengaruhi toleransi resiko pada investor. Dalam penelitian tersebut dinyatakan bahwa tingkat pendidikan mempunyai hubungan yang kuat dengan toleransi resiko dalam berinvestasi yaitu, semakin tinggi pendidikan seseorang maka akan semakin mempunyai tingkat toleransi yang tinggi terhadap resiko dalam berinvestasi.

\section{b. Tingkat Penghasilan}

Berdasarkan distribusinya, pada rumah tangga perumahan di pinggiran Kota Surakarta dapat dilihat bahwa $82 \%$ rumah tangga yang memiliki motif pembelian rumah untuk konsumsi, mempunyai penghasilan keluarga di bawah $\mathrm{Rp}$. 5.000 .000 tiap bulan dan $18 \%$ rumah tangga mempunyai penghasilan di atas Rp.5.000.000 tiap bulan. Sedangkan pada rumah tangga yang mempunyai motif investasi, 48,8\% merupakan rumah tangga yang mempunyai penghasilan di bawah Rp. 5.000.000 tiap bulan, dan 51,2\% merupakan rumah tangga yang mempunyai penghasilan di atas Rp. 5.000.000. Dari tabulasi silang (crosstabs) juga dapat diketahui bahwa individu/rumah tangga yang cenderung mempunyai motivasi pembelian rumah untuk investasi adalah individu /rumah tangga yang mempunyai penghasilan keluarga di atas $\mathrm{Rp}$. 5.000 .000 setiap bulannya.

Tabel 14. Uji Chi-Square Tingkat Penghasilan dengan Motif Pembelian Rumah

\begin{tabular}{|c|c|c|c|c|c|}
\hline \multicolumn{6}{|c|}{ Penghasilan * Motif Crosstabulation } \\
\hline & & & & & \\
\hline & & & Inves. & Kons. & Total \\
\hline \multirow{4}{*}{ Penghasilan } & \multirow[t]{2}{*}{$<5$ juta } & jml & 20 & 41 & 61 \\
\hline & & $\%$ & $48,8 \%$ & $82,0 \%$ & $67,0 \%$ \\
\hline & \multirow{2}{*}{$\geq 5$ juta } & jml & 21 & 9 & 30 \\
\hline & & $\%$ & $51,2 \%$ & $18,0 \%$ & $33,0 \%$ \\
\hline \multirow{2}{*}{\multicolumn{2}{|c|}{ Total }} & jml & 41 & 50 & 91 \\
\hline & & $\%$ & $100 \%$ & $100 \%$ & $100 \%$ \\
\hline
\end{tabular}

\begin{tabular}{|l|r|r|r|}
\hline & \multicolumn{1}{|c|}{ Value } & df & $\begin{array}{c}\text { Asymp. Sig. } \\
\text { (2-sided) }\end{array}$ \\
\hline Pearson Chi-Square & $11,249^{\mathrm{a}}$ & 1 & 0,001 \\
\hline Likelihood Ratio & 11,425 & 1 & 0,001 \\
\hline Linear-by-Linear Association & 11,126 & 1 & 0,001 \\
\hline N of Valid Cases & 91 & & \\
\hline
\end{tabular}

Dari perhitungan dengan uji Chi-Square, diperoleh hasil yang signifikan dengan nilai signifikansi sebesar 0,000 . Nilai ini lebih kecil dari $\alpha \quad(0,05)$, sehingga $\mathrm{H}_{0}$ ditolak. Hal ini menunjukkan bahwa terdapat hubungan yang kuat antara tingkat penghasilan dengan motif dalam membeli rumah.
Dengan demikian dapat disimpulkan bahwa semakin tinggi tingkat penghasilan keluarga dalam sebuah rumah tangga, maka semakin cenderung mempunyai keinginan untuk berinvestasi di bidang perumahan. Hal ini sesuai dengan yang dinyatakan Arrondel, dkk (2010). Arrondel menyatakan bahwa rumah tangga dengan penghasilan yang lebih besar cenderung mempunyai permintaan rumah sebagai barang investasi daripada untuk barang konsumsi. Rahmawati, dkk (2015) dalam penelitiannya tentang faktor yang mempengaruhi toleransi resiko pada investor juga menyatakan hal yang sama. Dalam penelitian tersebut dinyatakan bahwa tingkat penghasilan mempunyai hubungan yang kuat dengan toleransi resiko dalam berinvestasi, yaitu semakin tinggi penghasilan seseorang maka akan semakin mempunyai tingkat toleransi yang tinggi terhadap resiko dalam berinvestasi.

\section{c. Usia}

Berdasarkan distribusi dari hasil uji tabulasi silang, dapat dilihat bahwa sebagian besar rumah tangga perumahan di pinggiran Kota Surakarta yang membeli rumah berdasarkan motif untuk investasi berada di kelompok usia 31-40 tahun, yaitu sebanyak 48,8\%, kemudian diikuti oleh kelompok usia dibawah 30 tahun sebanyak 31,7\% dan kelompok usia di atas 40 tahun sebanyak 19,5 $\%$. Sedangkan pada rumah tangga yang membeli rumah untuk konsumsi, sebagian besar berada pada kelompok usia 31-40 tahun sebesar 44\%, kemudian diikuti oleh kelompok usia 40 tahun ke atas sebesar 38\% dan kelompok usia 30 tahun ke bawah sebesar $18 \%$. Apabila dilihat secara keseluruhan maka dapat dilihat bahwa sebagian besar rumah tangga yang membeli rumah berada pada kisaran umur 31-40 tahun, baik pada rumah tangga yang membeli rumah untuk konsumsi maupun untuk investasi.

Tabel 15. Uji Chi-Square Usia dengan Motif Pembelian Rumah

\begin{tabular}{|c|c|c|c|c|c|c|}
\hline \multicolumn{7}{|c|}{ Usia * Motif Crosstabulation } \\
\hline & & & Mol & & & \\
\hline & & & Inves. & \multicolumn{2}{|c|}{ Kons. } & Total \\
\hline \multirow{6}{*}{ Usia } & \multirow{2}{*}{$\leq 30$} & $\mathrm{jml}$ & 13 & & 9 & 22 \\
\hline & & $\%$ & $31,7 \%$ & 18, & $\% \%$ & $24,2 \%$ \\
\hline & \multirow{2}{*}{$31-40$} & jml & 20 & & 22 & 42 \\
\hline & & $\%$ & $48,8 \%$ & 44, & $0 \%$ & $46,2 \%$ \\
\hline & \multirow{2}{*}{$>40$} & $\mathrm{jml}$ & 8 & & 19 & 27 \\
\hline & & $\%$ & $19,5 \%$ & 38 , & $\% \%$ & $29,7 \%$ \\
\hline \multirow{2}{*}{\multicolumn{2}{|c|}{ Total }} & jml & 41 & & 50 & 91 \\
\hline & & $\%$ & $100 \%$ & \multicolumn{2}{|c|}{$100 \%$} & $100 \%$ \\
\hline & & & Value & df & \multicolumn{2}{|c|}{$\begin{array}{c}\text { Asymp. Sig. } \\
\text { (2-sided) }\end{array}$} \\
\hline \multicolumn{3}{|c|}{ Pearson Chi-Square } & $4,457^{\mathrm{a}}$ & 2 & & 0,108 \\
\hline \multicolumn{3}{|c|}{ Likelihood Ratio } & 4,550 & 2 & & 0,103 \\
\hline \multicolumn{3}{|c|}{ Linear-by-Linear Association } & 4,313 & 1 & & 0,038 \\
\hline \multicolumn{3}{|c|}{$\mathrm{N}$ of Valid Cases } & 91 & & & \\
\hline
\end{tabular}


Dari perhitungan dengan uji Chi-Square, diperoleh nilai signifikansi sebesar 0,108 . Nilai ini lebih besar dari $\alpha(0,005)$, sehingga $\mathrm{H}_{0}$ diterima. Hal ini menunjukkan bahwa terdapat tidak terdapat hubungan antara tingkat usia kepala rumah tangga dengan motif dalam membeli rumah. Sehingga dapat disimpulkan bahwa usia tidak menjadi pertimbangan individu/rumah tangga dalam melakukan investasi perumahan.

\section{d. Jenis Pekerjaan}

Berdasarkan distribusi dari hasil uji tabulasi silang (crosstabs) antara jenis pekerjaan dengan motif pembelian rumah, dapat dilihat bahwa pada rumah tangga yang membeli rumah untuk investasi, 65,9\% mempunyai pekerjaan sebagai pegawai swasta, 12,2 \% wiraswasta, 12,2\% pegawai negeri dan 9,8\% lainnya. Sedangkan pada rumah tangga yang membeli rumah untuk konsumsi, 60\% mempunyai pekerjaan sebagai pegawai swasta, $22 \%$ wiraswasta, $12 \%$ pegawai negeri dan $6 \%$ lainnya. Jika dilihat secara keseluruhan pada rumah tangga yang membeli rumah baik untuk konsumsi maupun untuk investasi, maka dapat dilihat bahwa sebagian besar rumah tangga yang membeli perumahan di pinggiran Kota Surakarta mempunyai pekerjaan sebagai pegawai swasta, yaitu sebanyak $62,6 \%$.

Tabel 16. Uji Chi-Square Jenis Pekerjaan dengan Motif Pembelian Rumah

\begin{tabular}{|c|c|c|c|c|c|}
\hline \multicolumn{6}{|c|}{ Pekerjaan * Motif Crosstabulation } \\
\hline & & & \multicolumn{2}{|c|}{ Motif } & \multirow[b]{2}{*}{ Total } \\
\hline & & & Inves. & Kons. & \\
\hline \multirow{8}{*}{ Pekerjaan } & \multirow{2}{*}{$\begin{array}{c}\text { Pegawai } \\
\text { Negeri }\end{array}$} & jml & 5 & 6 & 11 \\
\hline & & $\%$ & $12,2 \%$ & $12,0 \%$ & $12,1 \%$ \\
\hline & \multirow{2}{*}{$\begin{array}{c}\text { Pegawai } \\
\text { Swasta }\end{array}$} & jml & 27 & 30 & 57 \\
\hline & & $\%$ & $65,9 \%$ & $60,0 \%$ & $62,6 \%$ \\
\hline & \multirow{2}{*}{ Wiraswasta } & jml & 5 & 11 & 16 \\
\hline & & $\%$ & $12,2 \%$ & $22,0 \%$ & $17,6 \%$ \\
\hline & \multirow{2}{*}{ Lainnya } & jml & 4 & 3 & 7 \\
\hline & & $\%$ & $9,8 \%$ & $6,0 \%$ & $7,7 \%$ \\
\hline \multirow{2}{*}{\multicolumn{2}{|c|}{ Total }} & jml & 41 & 50 & 91 \\
\hline & & $\%$ & $100 \%$ & $100 \%$ & $100 \%$ \\
\hline
\end{tabular}

\begin{tabular}{|l|r|r|r|}
\hline & \multicolumn{1}{|c|}{ Value } & df & $\begin{array}{c}\text { Asymp. Sig. } \\
\text { (2-sided) }\end{array}$ \\
\hline Pearson Chi-Square & $1,769^{\mathrm{a}}$ & 3 & 0,622 \\
\hline Likelihood Ratio & 1,807 & 3 & 0,613 \\
\hline Linear-by-Linear Association & 0,025 & 1 & 0,875 \\
\hline N of Valid Cases & 91 & & \\
\hline
\end{tabular}

Dari perhitungan dengan uji Chi-Square, diperoleh hasil yang tidak signifikan dengan nilai signifikansi sebesar 0,622. Nilai ini lebih besar dari $\alpha(0,05)$, sehingga $\mathrm{H}_{0}$ diterima. Hal ini menunjukkan bahwa tidak terdapat hubungan antara jenis pekerjaan dengan motif dalam membeli rumah. Hal ini berbeda dengan yang dinyatakan Arrondel, dkk (2010), bahwa jenis pekerjaan seseorang mempengaruhi keputusan dalam melakukan investasi untuk perumahan.

\section{e. Jumlah Anggota Keluarga}

Dari uji tabulasi silang (crosstabs) antara jenis pekerjaan dengan motif pembelian rumah, menunjukkan bahwa pada rumah tangga yang membeli rumah untuk investasi, 68,3\% mempunyai jumlah anggota keluarga sebanyak 34 orang, $22 \%$ rumah tangga mempunyai anggota keluarga sebanyak 1-2 orang, dan 9,8\% rumah tangga mempunyai anggota keluarga lebih dari 4 orang. Sedangkan pada rumah tangga yang membeli rumah untuk konsumsi, $82 \%$ rumah tangga mempunyai jumlah anggota keluarga sebanyak 3-4 orang, $10 \%$ rumah tangga mempunyai anggota keluarga sebanyak lebih dari 4 orang, dan $8 \%$ rumah tangga mempunyai jumlah anggota keluarga sebanyak 1-2 orang. Jika dilihat secara keseluruhan, maka dapat dilihat sebagian besar rumah tangga responden merupakan keluarga yang mempunyai anggota keluarga sebanyak 3-4 orang, atau bisa disebut sebagai keluarga inti yang terdiri dari suami istri dan anak.

Tabel 17. Uji Chi-Square Jumlah Anggota Keluarga dengan Motif Pembelian Rumah

\begin{tabular}{|c|c|r|r|r|r|}
\hline \multicolumn{4}{|c|}{ Anggota Keluarga * Motif Crosstabulation } \\
\cline { 3 - 6 } \multicolumn{2}{|c|}{} & \multicolumn{2}{c|}{ Motif } & \multirow{2}{*}{ Total } \\
\cline { 3 - 6 } & \multirow{2}{*}{$1-2$} & jml & 9 & 4 & 13 \\
\cline { 3 - 6 } & $\%$ & $22,0 \%$ & $8,0 \%$ & $14,3 \%$ \\
\cline { 3 - 6 } $\begin{array}{c}\text { Anggota } \\
\text { Keluarga }\end{array}$ & \multirow{2}{*}{$3-4$} & jml & 28 & 41 & 69 \\
\cline { 3 - 6 } & \multirow{2}{*}{$>4$} & $\%$ & $68,3 \%$ & $82,0 \%$ & $75,8 \%$ \\
\cline { 3 - 6 } & & $\%$ & $9,8 \%$ & $10,0 \%$ & $9,9 \%$ \\
\hline \multirow{2}{*}{ Total } & jml & 41 & 50 & 91 \\
\cline { 3 - 6 } & & $\%$ & $100 \%$ & $100 \%$ & $100 \%$ \\
\hline
\end{tabular}

\begin{tabular}{|l|r|r|r|}
\hline & Value & df & $\begin{array}{c}\text { Asymp. Sig. } \\
\text { (2-sided) }\end{array}$ \\
\hline Pearson Chi-Square & $3,629^{a}$ & 2 & 0,163 \\
\hline Likelihood Ratio & 3,657 & 2 & 0,161 \\
\hline Linear-by-Linear Association & 1,872 & 1 & 0,171 \\
\hline N of Valid Cases & 91 & & \\
\hline
\end{tabular}

Dari perhitungan dengan uji Chi-Square, diperoleh hasil yang tidak signifikan dengan nilai signifikansi sebesar 0,163 . Nilai ini lebih besar dari $\alpha(0,05)$, sehingga $\mathrm{H}_{0}$ diterima. Hal ini menunjukkan bahwa terdapat tidak terdapat hubungan antara jumlah anggota keluarga dengan motif dalam membeli rumah. Sehingga dapat disimpulkan bahwa jumlah anggota keluarga tidak menjadi pertimbangan individu/rumah tangga dalam melakukan investasi perumahan.

\section{f. Tipe Rumah}

Berdasarkan hasil dari pengamatan pada perumahan di pinggiran Kota Surakarta yang menjadi penelitian diketahui bahwa tipe rumah menengah-mewah lebih cenderung digunakan sebagai sarana investasi daripada rumah dengan jenis tipe sederhana. Hal ini dapat dilihat 
berdasarkan distribusi dari hasil tabulasi silang antara jenis/tipe rumah dengan motif pembelian rumah yang menunjukkan bahwa pada rumah tangga yang membeli rumah untuk konsumsi sebanyak $68 \%$ rumah tangga yang membeli rumah dengan tipe rumah sederhana dan $32 \%$ merupakan rumah tangga yang membeli rumah dengen tipe menengah-mewah. Sebaliknya, pada rumah tangga yang membeli rumah untuk tujuan investasi, sebanyak $61 \%$ rumah tangga membeli rumah dengan tipe menengah-mewah dan $39 \%$ rumah tangga membeli rumah dengan tipe sederhana.

Tabel 18. Uji Chi-Square Tipe Rumah dengan Motif Pembelian Rumah

\begin{tabular}{|c|c|c|c|c|c|}
\hline \multicolumn{6}{|c|}{ Tipe Rumah * Motif Crosstabulation } \\
\hline & & & \multicolumn{2}{|c|}{ Motif } & \multirow[b]{2}{*}{ Total } \\
\hline & & & Inves. & Kons. & \\
\hline \multirow{4}{*}{$\begin{array}{l}\text { Tipe } \\
\text { Rumah }\end{array}$} & \multirow{2}{*}{ Sederhana } & jml & 16 & 34 & 50 \\
\hline & & $\%$ & $39,0 \%$ & $68,0 \%$ & $54,9 \%$ \\
\hline & \multirow{2}{*}{$\begin{array}{l}\text { Menengah- } \\
\text { Mewah }\end{array}$} & jml & 25 & 16 & 41 \\
\hline & & $\%$ & $61,0 \%$ & $32,0 \%$ & $45,1 \%$ \\
\hline \multirow{2}{*}{ Total } & & jml & 41 & 50 & 91 \\
\hline & & $\%$ & $100 \%$ & $100 \%$ & $100 \%$ \\
\hline
\end{tabular}

\begin{tabular}{|l|r|r|r|}
\hline & Value & df & $\begin{array}{c}\text { Asymp. Sig. } \\
\text { (2-sided) }\end{array}$ \\
\hline Pearson Chi-Square & $7,640^{\mathrm{a}}$ & 1 & 0,006 \\
\hline Likelihood Ratio & 7,728 & 1 & 0,005 \\
\hline Linear-by-Linear Association & 7,556 & 1 & 0,006 \\
\hline N of Valid Cases & 91 & & \\
\hline
\end{tabular}

Dari perhitungan dengan uji Chi-Square, juga diperoleh hasil yang signifikan dengan nilai signifikansi sebesar 0,006 . Nilai ini lebih kecil dari $\alpha \quad(0,05)$, sehingga $\mathrm{H}_{0}$ ditolak. Hal ini menunjukkan bahwa terdapat hubungan antara tipe rumah dengan motif dalam membeli rumah.

\section{KESIMPULAN}

Beberapa hasil yang dapat dismpulkan berdasarkan analisis-analisis di atas adalah:

1. Preferensi pemilihan perumahan antara konsumen yang membeli rumah untuk konsumsi berbeda dengan konsumen yang membeli rumah untuk investasi. Preferensi utama pemilihan perumahan bagi konsumen yang membeli rumah untuk konsumsi adalah 1) kondisi fisik lingkungan $(2,84)$; 2) pembiayaan rumah (2,76); dan lokasi dan aksesibilitas $(2,76)$. Sedangkan preferensi utama pemilihan rumah bagi konsumen yang membeli rumah untuk investasi adalah 1) kondisi fisik rumah $(2,83)$; 2) lokasi dan aksesibilitas $(2,80)$; dan 3$)$ kondisi fisik lingkungan $(2,78)$.

2. Karakteristik individu/rumah tangga yang berhubungan atau mempunyai pengaruh terhadap motivasi pembelian rumah adalah: 1) tingkat pendidikan (sig. 0,000); 2) tingkat penghasilan keluarga (sig. 0,001); dan 3) tipe perumahan (sig. 0,006).

\section{DAFTAR PUSTAKA}

Ajusa, Minarni. 2007. Analisis Faktor-Faktor yang Mempengaruhi Pemilihan Rumah Tinggal di Kecamatan Depok Kabupaten Sleman D.I Yogyakarta Tahun 2007. Tesis, Yogyakarta: Universitas Gadjah Mada.

Appraisal Institute. 2001. The Appraisal of Real Estate. Chicago.

Arrondel, Luc, Nuria Badenes, and Amedeo Spadaro. 2010. Consumption and Investment Motives in Housing Wealth Accumulation of Spanish Households. Working Paper, Social Science Research Network (SSRN).

Ehwan, Yeri. 2004. Analisis Faktor-Faktor yang Mempengaruhi Pemilihan Perumahan di Kota Bandar Lampung (Perbandingan Perumahan yang Cepat dan Lambat Terjual). Tesis, Yogyakarta: Universitas Gadjah Mada.

Green, Richard K., and Patric H. Hendershott. 1996. "Age, Housing Demand, and Real House Prices." Regional Sciences and Urban Economics 465-480.

Jain, Dhiraj, and Mandot Nikhil. 2012. "Impact of Demographic Factors on Investment Decision of Investors in Rajasthan." Researchers World 81-92.

Lusht, Kenneth. 1997. Real Estate Valuation: Principles and Aplication . Chicago: IRWIN.

Rahmawati, M. Dileep Kumar, Meyland Kambuaya, Farhand Jamil, and Saqib Muneer. 2015. "Determinants of The Risk Tolerance of Individual Investors." International Journal of Economics and Financial Issues 373-378.

Utama, Candra. 2011. "Rumah, Layakkah Menjadi Aset Untuk Investasi?" Bina Ekonomi (Fakultas Ekonomi Universitas Parahyangan) 15: 32-43.

Yunus, Hadi Sabari. 2012. Struktur Tata Ruang Kota. Yogyakarta: Pustaka Pelajar. 